\title{
Histone H3 Dimethyl Lys4
}

National Cancer Institute

\section{Source}

National Cancer Institute. Histone H3 Dimethyl Lys4. NCI Thesaurus. Code C107152.

A post-translationally modified form of histone $\mathrm{H} 3$ where the lysine residue at position 4

is dimethylated. This modification may be a marker for transcriptionally active genes. 